\title{
PENGARUH BUDAYA ORGANISASI DAN KOMPENSASI TERHADAP KEPUASAN KERJA DALAM MENINGKATKAN KINERJA KARYAWAN (STUDI KASUS PADA GENERASI BABY BOOMERS, X, Y DAN Z)
}

\author{
Stevanny Novianti Saliman \\ Program Studi Magister Manajemen Universitas Tarumanagara \\ gabriella.stevanny@yahoo.com
}

\begin{abstract}
The purpose of this study was to analyze the influence of organizational culture and compensation towards job satisfaction in improving the performance of employees on the baby boomers, generation $\mathrm{x}, \mathrm{y}$, and $\mathrm{z}$. Respondents in this research is done by taking a employee population from some random generation of working around the area of West Jakarta and Tangerang. The method is carried out in the form of survey method with the dissemination of questionnaires with population numbers 150 people. The results of this research show that the culture of the Organization and compensation have levels of influence significantly to job satisfaction in improving employee performance. Adjustment of organizational culture in the work environment and the granting of compensation in accordance with the work that is given to the employee can be influential with the job satisfaction of employees in a company as well as improve productivity or performance employees at the company.
\end{abstract}

Abstrak : Tujuan dari penelitian ini adalah untuk menganalisis pengaruh budaya organisasi dan kompensasi terhadap kepuasan kerja dalam meningkatkan kinerja karyawan pada generasi baby boomers, $\mathrm{x}, \mathrm{y}$, dan $\mathrm{z}$. Responden dalam penelitian ini dilakukan dengan cara mengambil jumlah populasi karyawan dari beberapa generasi secara acak yang bekerja di sekitar wilayah Tangerang dan Jakarta Barat. Metode yang dilakukan merupakan berupa metode survey dengan penyebaran kuesioner dengan jumlah populasi 150 orang. Hasil dari penelitian ini menunjukkan bahwa budaya organisasi dan kompensasi mempunyai tingkat pengaruh yang cukup signifikan terhadap kepuasan kerja dalam meningkatkan kinerja karyawan. Penyesuaian budaya organisasi dalam lingkungan kerja dan pemberian kompensasi yang sesuai dengan pekerjaan yang diberikan kepada karyawan dapat berpengaruh dengan kepuasan kerja karyawan pada suatu perusahaan serta meningkatan produktivitas atau kinerja karyawan pada perusahaan.

Keywords : organizational culture, compensation, job satisfaction, and Employee Performance.

\section{PENDAHULUAN}

Perbedaan generasi dalam lingkungan kerja menjadi salah subyek yang selalu muncul dalam perkembangan manajemen sumber daya manusia, dan konsep perbedaan generasi terus berkembang dari waktu ke waktu. Penelitian yang pertama tentang perkembangan nilai nilai generasi dilakukan oleh Manheim pada tahun 1952, penelitian tersebut didasarkan pada tulisan - tulisan dalam bidang sosiologi tentang generasi pada kisaran tahun 1920 sampai dengan tahun 1930. Mannheim (1952) mengungkapkan bahwa generasi yang lebih muda tidak dapat bersosialisasi dengan sempurna karena adanya gap antara nilai - nilai ideal yang diajarkan oleh generasi yang lebih tua dengan realitas yang dihadapi oleh generasi muda tersebut, lebih lanjut dikatakan bahwa lokasi sosial memiliki efek yang besar terhadap terbentuknya kesadaran individu. Menurut Manheim (1952) generasi adalah suatu konstruksi sosial dimana didalamnya terdapat sekelompok orang yang memiliki kesamaan umur dan 
pengalaman historis yang sama. Lebih lanjut Manheim (1952) menjelaskan bahwa individu yang menjadi bagian dari satu generasi, adalah mereka yang memiliki kesamaan tahun lahir dalam rentang waktu 20 tahun dan berada dalam dimensi sosial dan dimensi sejarah yang sama. Definisi tersebut secara spesifik juga dikembangkan oleh Ryder (1965) yang mengatakan bahwa generasi adalah agregat dari sekelompok individu yang mengalami peristiwa - peristiwa yang sama dalam kurun waktu yang sama pula. Dalam beberapa tahun terakhir definisi generasi telah berkembang, salah satunya adalah definisi menurut Kupperschmidt's (2000) yang mengatakan bahwa generasi adalah sekelompok individu yang mengidentifikasi kelompoknya berdasarkan kesamaan tahun kelahiran, umur, lokasi, dan kejadian - kejadian dalam kehidupan kelompok individu tersebut yang memiliki pengaruh signifikan dalam fase pertumbuhan mereka. Dari beberapa definisi tersebut teori tetang perbedaan generasi dipopulerkan oleh Neil Howe dan William Strauss pada tahun 1991. Howe \& Strauss $(1991,2000)$ membagi generasi berdasarkan kesamaan rentang waktu kelahiran dan kesamaan kejadian - kejadian historis. Pembagian generasi tersebut juga banyak dikemukakan oleh peneliti - peneliti lain dengan label yang berbeda - beda, tetapi secara umum memiliki makna yang sama. Sebagai contoh menurut Martin \& Tulgan (2002) Generasi Y adalah generasi yang lahir pada kisaran tahun 1978, sementara menurut Howe \& Strauss (2000) generasi Y adalah generasi yang lahir pada tahun 1982, hal tersebut terjadi karena adanya perbedaan skema yang digunakan untuk mengelompokkan generasi tersebut, karena peneliti - peneliti tersebut berasal dari Negara yang berbeda. Perumusan masalah dalam penelitian ini mengacu pada latar belakang mengenai adanya indikasi bahwa budaya organisasi dan kompensasi yang ada kurang memiliki pengaruh yang positif terhadap kepuasan kerja dan kinerja karyawannya. Dan pada penelitian ini, peneliti akan mengacu pada ke empat generasi yang usianya masuk dalam kategori karyawan. Peneliti akan membandingkan, pada generasi manakah karyawan akan lebih produktif, pada generasi mana juga karyawan akan lebih mempunyai kinerja yang paling ideal.

\section{TINJAUAN PUSTAKA}

Sumber daya manusia kini makin berperan dalam keberhasilan suatu organisasi. Banyak organisasi menyadari bahwa unsur manusia dalam suatu organisasi dapat memberikan keunggulan untuk bersaing. Mereka membuat sasaran, strategi, inovasi, dan pencapaian tujuan organisasi. Oleh karena itu, sumber daya manusia merupakan unsur yang paling penting bagi organisasi. Dalam unsur 6M yaitu unsur Man (manusia) dapat dikembangkan menjadi suatu ilmu manajemen yang disebut manajemen sumber daya manusia.

Manajemen Sumber Daya Manusia memiliki tugas untuk mengelola dan mengembangkan manusia se-efektif mungkin agar sumber daya manusia menjadi loyal dan mampu bekerja secara optimal sesuai dengan kebutuhan perusahaan.

Pada tahapan karir, hampir semua orang perlu memahami budaya organisasi dan bagaimana cara bekerja karena akan mempunyai pengaruh kuat pada kehidupan kerjanya. Kebanyakan orang berpikir bahwa pekerjaan hanyalah sekedar pekerjaan, akan tetapi mereka telah memilih jalan hidup yang akan ditempuh. Budaya organisasi membentuk responsnya dengan cara yang kuat, tetapi cerdik. Budaya organisasi dapat membentuk mereka menjadi pekerja yang mampu bekerja cepat atau lambat, menjadi manajer yang keras atau bersahabat, menjadi pemain tim atau individual.

Kompensasi merupakan hal yang kompleks dan sulit, karena didalamya melibatkan dasar kelayakan, logika, rasional, dan dapat dipertanggungjawabkan serta menyangkut faktor emosional dari aspek tenaga kerja. Kompensasi diberikan dengan tujuan memberikan rangsangan dan motivasi kepada tenaga kerja untuk meningkatkan prestasi kerja, serta efisiensi dan efektivitas produksi. Oleh karena itu, bila kompensasi diberikan secara 
benar, para karyawan akan lebih terpuaskan dan termotivasi untuk mencapai sasaransasaran organisasi.

Nelson and Quick (2006) mengungkapkan bahwa :

“ kepuasan kerja dipengaruhi 5 dimensi spesifik dari pekerjaan yaitu gaji, pekerjaan itu sendiri, kesempatan promosi, supervisi dan rekan kerja."

- Gaji : sejumlah upah yang diterima dan tingkat dimana hal ini bisa diangap sebagai hal yang pantas dibandingkan dengen orang lain di dalam organisasi. Karyawan memandang gaji sebagai refleksi dari bagaimana manajemen memandang kontribusi mereka terhadap perusahaan.

- Promosi merupakan factor yang berhubungan dengan ada atau tidaknya kesempatan memperoleh peningkatan karier selama bekwerja. Kesempatan inilah yang memiliki pengaruh yang berbeda pada kepuasan kerja.

- Supervise merupakan kemampuan atasan untuk memberikan bantuan teknis dan dukungan prilaku kepada bawahan yang mengalami permasalahan dalam pekerjaan.

- Rekan Kerja merupakan tungakat dimana rekan kerja yang pandai dan mendukung secara social merupakan factor yang berhubungan dengan hubungan antara pegawai dan atsannya dan dengan pegawai lainnya baik yang sama maupun yang berbeda jenis pekerjaan.

\section{Hipotesis Penelitian}

Budaya Organisasi dan Kompensasi berpengaruh pada kepuasan kerja karyawan dalam meningkatkan kinerja karyawan.

\section{METODE PENELITIAN}

\section{Populasi dan Sampel Penelitian}

Pada penelitian ini, penuls menetapkan populasi penelitian adalah sampling dari beberapa karyawan yang berasal dari generasi baby boomers, $\mathrm{x}, \mathrm{y}$ dan $\mathrm{z}$ sebanyak 150 orang.

\section{Metode Pengumpulan Data}

Dalam penelitianini teknik pengumpulan data yang digunakan oleh peneliti yaitu berupa penyebaran kuisioner (angket) yang dilakukan dengan membagikan pernyataan tertulis dari beberapa sampling karyawan yang berasal dari generasi baby boomers, $\mathrm{x}, \mathrm{y}$ dan $\mathrm{z}$ sebanyak 150 orang.

\section{Variabel Penelitian}

Menurut Supranto (2009:43) operasionalisasi konsep atau variabel berarti upaya agar suatu konsep yang abstrak (tersembunyi/tidak terlihat) bisa diukur. Konsep yang abstrak harus diuraikan menjadi dimensi, kemudian dimensi diuraikan menjadi elemen, baru dilakukan pengukuran, misalnya dengan menggunakan pertanyaan - pertanyaan. Budaya organisasi (X1) merupakan keyakinan dan nilai - nilai organisasi yang dijiwai oleh seluruh anggotanya dalam melakukan pekerjaan sebagai cara yang tepat untuk memahami, memikirkan dan merasakan masalah - masalah yang terkait, sehingga akan menjadi sebuah nilau atau aturan dalam organisasi tersebut. Kompensasi (X2) merupakan segala sesuatu yang diterima dapat berupa fisik maupun non fisik dan harus dihitung dan diberikan kepada seseorang yang umumnya merupakan objek yang dikecualikan dari pajak pendapatan. Kinerja karyawan (Y2) adalah hasil kerja yang dicapai seseorang sesuai dengan tanggung jawab yang telah diberikan, yang dalam penelitian ini merupakan variabel moderasi atau variabel Y2. Kepuasan kerja (Y1) adalah sikap emosional yang menyenangkan dan mencintai pekerjaannya. Sikap ini dicerminkan oleh moral kerja, kedisiplinan dan prestasi kerja. Kepuasan kerja dinikmati dalam pekerjaan, luar pekerjaan, dan kombinasi dalam dan luar pekerjaan. 


\section{Metode Analisa}

Pada penelitian ini penulis melakukan pengujian dengan beberapa metode yaitu uji validitas, reabilitas, uji asumsi klasik, dan uji t serta uji f.

\section{Pengujian \\ Hasil dan Pembahasan}

Uji $\mathrm{F}$ dalam analisis regeresi berganda berfungsi untuk menunjukan apakah semua variabel independen atau variabel bebas yang dimasukkan dalam model mempunyai pengaruh secara bersama-sama terhadap variabel dependen atau variabel terkait. Dari hasil uji F untuk variabel budaya organisasi, kompensasi dan kepuasan kerja ini dapat dilihat bahwa nilai $\mathrm{F}$ di tabel 4.24 sebesar 43,226 > F tabel $(3,06)$ hal ini berarti bahwa variabel kompensasi dan budaya organisasi mempunyai pengaruh terhadap variabel kepuasan kerja. Dengan demikian kita dapat mengatakan model regresi yang diperoleh merupakan model regresi yang signifikan.

Pada uji regresi $\mathrm{R}$ square, dapat diketahui bahwa nilai koefisien penentu atau $\mathrm{R}$ square adalah sebesar 0,37. Hal ini berarti variasi variabel dependen (kepuasan kerja) dapat dijelaskan oleh variabel independen budaya organisasi dan kompensasi sebesar 37\%. Sedangkan sisanya 63\% dipengaruhi oleh faktor lain yang tidak diteliti oleh peneliti.

Dari hasil uji R2 pada pengaruh Budaya Organisasi dan Kompensasi terhadap Kepuasan Kerja dalam meningkatkan Kinerja Karyawan dapat dilihat bahwa budaya organisasi cukup mempengaruhi tingkat kepuasan kerja karyawan dalam suatu perusahaan, namun ada beberapa hal lain juga yang tidak diteliti oleh peneliti yang dapat mempengaruhi tingkat kepuasan kerja karyawan serta mempengaruhi kinerja karyawan juga dalam suatu organisasi / perusahaan.

Pada hasil uji multikolinieritas juga menunjukkan bahwa tidak ada nilai VIF dari kedua variabel independen yang memiliki nilai $\leq 10,00$, maka kesimpulan yang diperoleh adalah tidak terjadi gejala multikolinieritas pada variabel independennya. Dan dapat dilihat koefisien untuk persamaan regresi dari penelitian ini, yang dapat disusun dalam persamaan matematis sebagai berikut : Y2 $=1.360+0.233 \times 1+0.150 \times 2+0.305$ Y1

\section{PENUTUP}

\section{Kesimpulan}

Berdasarkan hasil pengujian yang telah dilakukan oleh peneliti dan telah dibahas pada bagian hasil dan pembahasan dapat disimpulkan bahwa variable budaya organisasi dan kompensasi akan memberi pengaruh pada kepuasan kerja dalam meningkatkan kinerja karyawan namun ada beberapa hal lain juga yang tidak diteliti oleh peneliti yang dapat mempengaruhi tingkat kepuasan kerja karyawan serta mempengaruhi kinerja karyawan juga dalam suatu organisasi / perusahaan. Dengan adanya budaya organisasi yang baik dan pemberian kompensasi yang sesuai bagi para karyawan maka akan mempengaruhi tingkat kepuasan kerja dan kinerja karyawan pada suatu perusahaan walaupun tidak hanya dari kedua hal tersebut karyawan dapat merasa puas dan berkinerja dengan baik.

\section{Saran}

Bagi perusahaan, memperhatikan kondisi budaya organisasi dan komponen kompensasi cukup penting dalam hal meningkatkan kinerja karyawan agar dapat mencapai tujuan perusahaan yang diinginkan. Perusahaan harus melakukan evaluasi secara rutin terhadap target kinerja yang telah diberikan kepada para karyawan. Dan menganalisis hal apa saja yang menjadi faktor tidak tercapainya target kinerja sehingga dapat disesuaikan dengan kondisi yang ada sekarang ini. Dengan budaya organisasi dan kompensasi yang baik ada di perusahaan maka dapat dikatakan bahwa perusahaan tersebut bertumbuh dengan baik. Akan tetapi perusahaan harus selalu memperhatikan dan meningkatkan kinerja karyawan karyawan 
karena karyawan merupakan aset penting bagi perusahaan dalam pencapaian tujuan perusahaan dan tentunya sebuah perusahaan harus dapat mensejahterakan karyawannya. Bagi

peneliti selanjutnya, penulis dapat memberikan saran agar dapat menambahkan variabel independen lainnya agar dapat menjelaskan pengaruhnya terhadap variabel dependen dengan lebih maksimal lagi dan juga dapat menambah waktu penelitian sehingga dapat mendapatkan jumlah responden lebih banyak lagi. Dan untuk para pembaca penelitian ini, penelitian ini dapat menjadi referensi apabila pembaca melakukan penelitian yang sejenis, pembaca juga dapat memberikan kinerja yang terbaik bagi diri sendiri dan perusahaan dimana tempat kita bekerja, memaksimalkan segala fasilitas yang diberikan peusahaan supaya dapat meraih target kinerja yang diberikan peusahaan.

\section{DAFTAR PUSTAKA}

Afifudin, H. 2013. Dasar - Dasar Manajemen. CV. Bandung : CV. Mandar Maju.

Hadi. (2006). Pengaruh Budaya Organisasi dan Iklim Organisasi terhadap kepuasan kerja.

Hasibuan. (2011). Manajemen Sumber Daya Manusia. Jakarta : Bumi Aksara Jakarta :

Kencana

Marwansyah. 2010. Manajemen Sumber Daya Manusia. Edisi Kedua. Bandung : Alfabeta.

Robbins, Stephen P. (2013). Organizational Behavior. New York : Prentice Hall PTR.

Scott Rood, Andrew Holdnak. (2013). An Analysis of Compensation Patterns and Job Satisfaction Issues of Resort RecreationProfessional. Journal of Tourism Insights Volume 4, Issue 1 7-23-2013.

Sutrisno, Edy. (2013). Manajemen Sumber Daya Manusia. Edisi Pertama. Cetakan Pertama. Vecchio, Robert P. (2013). Organizational Behavior. Australia. Kreiner Robert, Kinicki Angelo. (2013). Organizational Behavior, Pennsylvania State University, USA : McGrawHill.

Wibowo. (2011). Budaya Organisasi. Jakarta : Rajawali Pers

Handoko, Hani. (2003). Manajemen Personalia dan Sumber Daya Manusia. Yogyakarta : Penerbit BPFE.

Jackson, Susan E., Schuler., dan Werner. Pengelolaan Sumber Daya Manusia (Edisi 10). Salemba Empat.

Hasibuan. Malayu S.P. (2013). Manajemen Sumber Daya Manusia. Edisi Revisi. Bumi Aksara. Jakarta.

Mangkunegara, Anwar Prabu. (2005). Manajemen Sumber Daya Manusia Perusahaan. Cetakan Keenam. PT Remaja Rosdakarya . Bandung.

Rivai, V., Sagala, E. J. (2009). Manajemen Sumber Daya Manusia untuk Perusahaan dari Teori ke Praktik. PT Raja Grafindo Persada. Jakarta.

Sedarmayanti. (2009). Dasar - Dasar Pengetahuan Tentang Manajemen Perkantoran. CV Mandar Maju. Bandung.

Sekaran, Uma. (2010). Research Methods for Business a Skill Building Approach. John Wiley and Sons. Inc. USA.

Sugiyono. (2013). Metode Penelitian Kuantitatif Kualitatif dan R \& D. Bandung : Alfabeta Cooper, Donald R, Pamela S Schindler. (2011). Business Research Method. Edisi 11, The McGraw-Hill Companies, Inc, New York.

Malhotra, Naresh K. (2012). Basic Marketing Research ; Integration Of Social Media. Pearson. New Jersey.

Mats Alvesson. (2012). "Understanding Organizational Culture”. SAGE Publications.

Simamora, Henry. (2002) Manajemen Sumber Daya Manusia. PT Gramedia Pustaka Umum, Jakarta. 
Zemke Ron, Raines Claire, Flipczak Bob. (2000). "Generations at Work: Managing the Clash of Veterans, Boomers, Xers, and Nexters in Your Workplace". America.

Nelson, D.L., and C. J. Quick. 2006. Organizatonal Behavior Foundations Realities and Challenges. Thompson South Western United States of America. 
